\title{
Types of acute phase reactants and their importance in vaccination (Review)
}

\author{
RAFAAT H. KHALIL ${ }^{1}$ and NABIL AL-HUMADI ${ }^{2}$ \\ ${ }^{1}$ Department of Biology, College of Science and Technology, Florida Agricultural and Mechanical University, \\ Tallahassee, FL 32307; ${ }^{2}$ Office of Vaccines, Food and Drug Administration, Center for Biologics Evaluation and Research, \\ Silver Spring, MD 20993, USA
}

Received May 10, 2019; Accepted November 25, 2019

DOI: 10.3892/br.2020.1276

\begin{abstract}
Vaccines are considered to be one of the most cost-effective life-saving interventions in human history. The body's inflammatory response to vaccines has both desired effects (immune response), undesired effects [(acute phase reactions (APRs)] and trade-offs. Trade-offs are more potent immune responses which may be potentially difficult to separate from potent acute phase reactions. Thus, studying acute phase proteins (APPs) during vaccination may aid our understanding of APRs and homeostatic changes which can result from inflammatory responses. Depending on the severity of the response in humans, these reactions can be classified as major, moderate or minor. In this review, types of APPs and their importance in vaccination will be discussed.
\end{abstract}

\section{Contents}

1. Introduction

2. Inflammation and APPs

3. Types of APPs

4. Vaccines and APP

5. Effect of adjuvant systems on APP

6. Conclusion

\section{Introduction}

The association between the strength of the acute phase response and vaccination efficacy is of key importance to

Correspondence to: Dr Nabil Al-Humadi, Office of Vaccines, Food and Drug Administration, Center for Biologics Evaluation and Research, 10904 New Hampshire Avenue, Silver Spring, MD 20993, USA

E-mail: nabil.alhumadi@fda.hhs.gov

Key words: acute phase reactants, c-reactive proteins, inflammation, vaccine human and veterinary medicine. Proteins which are expressed in the acute phase are potential biomarkers for the diagnosis of inflammatory disease, for example, acute phase proteins (APPs) are indicators of successful organ transplantation and can be used to predict the ameliorative effect of cancer therapy $(1,2)$. APPs are primarily synthesized in hepatocytes. The acute phase response is a spontaneous reaction triggered by disrupted homeostasis resulting from environmental disturbances (3). Acute phase reactions (APRs) usually stabilize quickly, after recovering from a disruption to homeostasis within a few days to weeks; however, APPs expression levels often remain elevated in long lasting infection and chronic disease states, such as cancer (4-6).

Classification of acute phase reactions is dependent on the change in APP concentration: A 10-100-fold elevation is considered major; a 2-10-fold elevation is considered moderate; and a less than 2-fold elevation is considered minor (7). The APPs elevated in a major APR include C-reactive protein (CRP) and serum amyloid (SA); the APPs elevated in a moderate APR include $\alpha 1$-acid glycoprotein (AGP); and the APPs elevated in a minor APR include fibrinogen, haptoglobin (Hp) and ceruloplasmin (Cp) (8).

In response to infection, the liver synthesizes a large quantity of APPs (8). There are 8 proteins which are overexpressed in APRs denoted as 'positive' APPs, including Hp, SA, fibrinogen, $\mathrm{Cp}$, AGP, $\alpha-1$ antitrypsin (AAT), lactoferrin (Lf) and CRP. Similarly, there are a number of 'negative' APPs the expression levels of which are reduced, including albumin, transferrin and transthyretin (8).

The APP is elicited by cytokines, including those functioning as positive and negative growth factors and cytokines with proinflammatory or anti-inflammatory activity. Positive or negative growth factor cytokines involved include: Interleukin (IL)-2; IL-3; IL-4; IL-7; IL-10; IL-11; IL-12; and granulocyte-macrophage colony stimulating factor (9). Proinflammatory cytokines involved include tumour necrosis factor (TNF)- $\alpha / \beta$; IL- $1 \alpha / \beta$; IL-6; IFN- $\alpha / \gamma$; IL-8; and macrophage inhibitory protein-1 (6). Cytokines involved in the anti-inflammatory response include: IL-1 receptor antagonists; soluble IL-1 receptors; IL-1 binding protein; and TNF- $\alpha$ binding protein. Table I shows acute phase reactants associated, inflammatory cytokines and references. 


\section{Inflammation and APPs}

The acute inflammatory reaction is an essential immune response required for vaccinations to initiate temporary simulated immunity. The innate response is the first branch of the immune system stimulated by invading pathogens, should they cross the body's anatomical and chemical barriers. The innate immune system is also activated by APP synthesis as these molecules mediate inflammation.

After vaccination, pro-inflammatory cells are activated and produce cytokines which diffuse into the extracellular fluid and circulate in the blood. In response, the liver upregulates the synthesis of APPs, preceding the specific immune reaction within a few hours. Monitoring APP expression levels may be an indicator of efficacy of a vaccine in stimulating the innate immune system and may be a useful biomarker in the future development of vaccines.

\section{Types of APPs}

C-reactive protein (CRP). CRP is a member of the short evolutionarily conserved pentraxin group of plasma proteins, consisting of 5 identical non-glycosylated peptide subunits which link to form a cyclic pentamer structure $(10,11)$. CRP is produced as a result of pro-inflammatory cytokine signaling primarily mediated by neutrophils and monocytes. CRP concentration is elevated during infection or inflammation as part of the innate immune response and alteration of CRP plasma concentration is dependent on the rate of CRP synthesis and the severity of infection (10). The half-life of CRP in plasma is $\sim 19 \mathrm{~h}$ and is cleared by the urinary system $(10,12)$ and CRP stimulates immune cells by binding to $\mathrm{Fc} \gamma$ receptors $(\mathrm{Fc} \gamma \mathrm{R})$ on leukocytes (monocytes, neutrophils and cells of a myeloid lineage) and increases production of $\operatorname{IgG}$, linking the innate and adaptive immune systems (13). CRP-Fc $\gamma R$ binding also facilitates the anti-inflammatory responses (14).

It has been proposed that CRP may have value as a diagnostic marker for active inflammation and infection. IL-6, IL-1 and TNF- $\alpha$ trigger hepatocyte mediated synthesis of CRP in response to active infection or inflammation. Subsequently, CRP binding to bacterial polysaccharides in the presence of calcium activates downstream compliment pathways and ultimately results in phagocytosis $(15,16)$; however, the primary function of CRP is to recognize foreign pathogens and components of damaged cells through binding to phosphocholine (PC), a terminal head group of the lipoteichoic acid which is a component of the cell walls of certain Gram positive bacteria and a component of the mammalian cell membrane. In normal healthy cells, phosphocholine is not exposed however, when cells are damaged or are dying, CRP is able to bind to the PC present on the cell membrane (17). In addition, CRP promotes complement fixation, binding to phagocytized cells and triggers the elimination of cells targeted by the inflammatory response pathway (17-19). There is a direct association between the elevated levels of CRP and the risk of coronary artery and cerebrovascular thrombosis interfering with endothelial nitric oxide (NO) bioavailability, by decreasing endothelial NO synthase expression and increasing the production of reactive oxygen species $(20,21)$.
In the USA, CRP levels in patients tend to be higher in females compared with males in healthy humans (2.7 vs. $1.6 \mathrm{mg} / 1$, respectively) and these levels are exacerbated with age, for example one study reported CRP levels of $1.4 \mathrm{mg} / 1$ between the ages of $20-29$ vs. $2.7 \mathrm{mg} / \mathrm{l}$ in those over 80 (22). Meanwhile, ethnicity has little effect on CRP levels (22).

When CRP was studied in non-human species, rabbits served as the primary experimental model due to their susceptibility to infection and the similarity of pathogenesis to what is observed in humans, rabbit CRP behaves more similar to human CRP compared with rat CRP in terms of its dynamic changes during acute phase response $(13,23)$.

Haptoglobin $(H p)$. Hp is a glycoprotein synthesized in the liver and present in serum at concentrations of 3-30 $\mu \mathrm{mol} / 1$. Serum levels of $\mathrm{Hp}$ increase 3-8-fold in response to inflammation and injury and $\mathrm{Hp}$ is eliminated from the plasma in 3-5 days $(24,25)$. $\mathrm{Hp}$ binds free hemoglobin $(\mathrm{Hb})$ for detoxification and $\mathrm{Hb}$ is highly toxic due to its heme group which mediates the generation of hydroxyl radicals (24). The elimination of $\mathrm{Hb}$ and its iron constituent occurs by the formation of a noncovalent $\mathrm{Hb}-\mathrm{Hp}$ complex which is released into the blood by intravascular hemolysis and subsequently removed by reticuloendothelial receptor-mediated endocytosis and tissue macrophages via interacting with CD163 cell-surface receptor (26). Free hemoglobin is very toxic to the human body due to its ability to bind $\mathrm{NO}$ which is a key modulator of vascular tone (27). Hp mediated NO binding prevents NO activity in vascular smooth muscle cells resulting in changes to vasomotor constriction, potentially causing endothelial damage which may contribute to cardiovascular disease, and pulmonary and systemic hypertension (28).

Hp has several functions in the cellular and humoral aspects of the innate and adaptive immune systems (24), including inhibiting prostaglandin production, enhancing the antibody production, leukocyte recruitment and migration, modulation of cytokine release, which are the regulatory mediators secreted by $\mathrm{T}$ cells and other immunoactive cells following an injury, infection and tissue repair (29-31). Conditions associated with a reduction or absence of Hp, such as hypohaptoglobinemia or ahaptoglobinemia, result in severe allergies involving the skin, lungs and anaphylaxis (29-31). Hp also suppresses T cell proliferation, including Th2 and Th4 cytokines synthesis (32), and cyclooxygenase and lipoxygenase activity, thus contributing to the regulation of the immune response to potentially damaging inflammation or infection (33).

Serum amyloid A (SAA). SAA is an APP and a apolipoprotein, which binds to high-density lipoproteins (HDL) in the plasma, During an APR, the fraction of apoA1 in HDL falls while that of SAA rises, becoming the predominant apolipoprotein (apo SAA), exceeding apo A-1 (the major apolipoprotein of native HDL) and reduces the effectiveness of HDL recycling cholesterol to the liver during inflammation (34). SAA displaces apolipoprotein A-1 from HDL, and becomes the predominant circulating HDL3 apolipoprotein mediating reverse cholesterol transport and inhibiting the LDL oxidation. LDL oxidation promotes foam cell formation, and thus, this reduces the risk of atherosclerosis (27). SAA is found at concentrations of $40 \mathrm{ug} / \mathrm{ml}$ in healthy males in the UK (34). During acute infection, SAA plasma levels are elevated by up to 1,000 -fold (34). 
Table I. Acute phase reactants, associated inflammatory cytokines and references.

A, Positive acute phase reactants

\begin{tabular}{|c|c|c|c|}
\hline Author, year & Reactant & Associated cytokines & (Refs.) \\
\hline Sharpe-Timms et al, 2010 & Haptoglobin & IL1 $\beta$, IL-6, IL-8, TNF- $\alpha$, & (9) \\
\hline He et al, 2006 & Serum amyloid & IL1 $\beta$, IL-6, IL-8, IL-12, IL-23 & $(143)$ \\
\hline Lu et al, 2015 & Fibrinogen & IL-6, IL-6, TNF- $\alpha$, IL- $1 \beta$, IL-8 & $(144)$ \\
\hline Lazzaro et al, 2014 & Ceruloplasmin & IL- $1 \beta$, TNF- $\alpha$, IFN-1 & $(145)$ \\
\hline Martinez Cordero et al, 2008 & $\alpha-1$ acid glycoprotein & TNF- $\alpha$, IL-1, IL-6 & $(146)$ \\
\hline de Serres and Blanco, 2014 & $\alpha-1$ antitrypsin & TNF- $\alpha$, IL-6, IL-1 $\beta$, IL- 8, IL-32 & $(147)$ \\
\hline Haversen et al, 2002 & Lactoferrin & TNF- $\alpha$, IL-6, IL-1 $\beta$, IL- 8 & $(148)$ \\
\hline Du Clos, 2000 & C-reactive protein & IL-6, IL-1a, IL-1 $\beta$, TNF- $\alpha$ & $(149)$ \\
\hline
\end{tabular}

$\mathrm{B}$, Negative acute phase reactants

\begin{tabular}{llll}
\hline Author, year & \multicolumn{1}{c}{ Reactant } & \multicolumn{1}{c}{ Associated cytokines } & (Refs.) \\
\hline Spadaro et al, 2014 & Albumin & IL-6, TNF- $\alpha$ & $(150)$ \\
Feelders et al, 1998 & Transferrin & IL-6, TNF- $\alpha$, IL1 & $(151)$ \\
Bartalena et al, 1992 & Transthyretin & IL-6, IL-1, TNF- $\alpha$ & $(152)$ \\
\hline
\end{tabular}

IL, interleukin; TNF, tumor necrosis factor.

SAA has been shown to be an efficient carrier of retinol during an infection, while retinol is important for promotion and maturation of innate immune cells, expression of retinol transporter is reduced during infection, providing insight into the underlying mechanisms involved in the redirection of retinol in response to infection compensating to the markedly reduced levels of serum retinol binding protein transporter following a microbial infection (35). During inflammation, macrophages and monocytes present at the inflammatory site release cytokines, such as IL-6, initiating the induction of SAA synthesis and release of SAA by the liver into the plasma (16).

SAA is a conserved protein which circulates in the plasma and is able to bind to surface ligands of microbial pathogens in a calcium-dependent manner (36). SAA binds to microbial polysaccharides, which are part of the cell wall of gram-negative bacteria, and matrix components via carbohydrate determinant links, including heparin, 6-phosphorylated mannose, 3 -sulfated saccharides and the 4,6-cyclic pyruvate acetal of galactose $(37,38)$. SAA binds to apoptotic and necrotic cells facilitating its clearance in vivo (39).

Most species possess two main acute phase apo SAA isoforms of hepatic origin in their serum, SAA1 and SAA2 are APPs with the ability to form amyloid proteins in vivo and SAA1 and SAA2 represent multiple allelic forms which are alternatively expressed by three different genes in humans (40). SAA4 is constitutively expressed across a number of tissues and has been shown to form amyloid when mutated (41). SAA1a is frequently present in amyloid fibrils and is possibly the most amyloidogenic form of SAA1. Although the majority of SAA1 and SAA2 are found bound to HDL, they are only a minor protein component in a healthy state. This classification helps differentiate between regulated acute phase reactants of hepatic origin or constitutive proteins (42).

Fibrinogen. Fibrinogen is an important protein involved in blood clotting, homeostasis, inflammation and tissue repair. Fibrinogen is a $340-\mathrm{kDa}$ soluble glycoprotein found in the blood, and a major component of fibrin which is synthesized in the liver. In healthy adults, fibrinogen plasma levels are $\sim 150-400 \mathrm{mg} / \mathrm{dl}$, and during infection, expression levels of fibrinogen can increase by $\leq 20$-fold (43). At a site of injury, fibrinogen facilitates aggregation of activated platelets through binding to glycoprotein IIb/IIIa cell surface receptor (43), triggering platelet adhesion, and subsequently, thrombin cleaves fibrinogen into fibrin monomers which polymerize to form a clot $(44,45)$ and are stabilized by activated factor XIII (46). The strength of the fibrin clot is influenced by the concentration of fibrinogen (44). A structural scaffold is formed by the fibrin clot onto which leukocyte platelets and fibroblasts adhere and infiltrate the injury site. Extravascular plasma generates thrombin which ultimately leads to deposition of fibrinogen (47), therefore injury, infection and auto-immunity are associated with extravascular fibrinogen $(48,49)$.

Ceruloplasmin $(\mathrm{Cp})$. Cp is a major copper transport protein present in the plasma and is produced by the hepatic parenchymal cells (50). Human $\mathrm{Cp}(\mathrm{hCp})$ is a $132 \mathrm{kDa} \alpha 2$-globulin which can bind up to six copper ions, and serum concentration levels in healthy individuals are $\sim 0.2-0.6 \mathrm{mg} / \mathrm{ml}$, which increases $>2$-fold during inflammation (51). Overall, $95 \%$ of serum copper is bound to $\mathrm{Cp}$ (52). hCp has ferroxidase activity and functions in the mobilization of iron for transport by 
oxidizing $\mathrm{Fe}^{2+}$ to the less reactive $\mathrm{Fe}^{3+}$ and incorporating $\mathrm{Fe}^{3+}$ into apotransferrin (53). This oxidation prevents the formation of reactive oxygen species and toxic products of iron $(54,55)$. Therefore, $\mathrm{Cp}$ has an essential role in iron metabolism and the elimination of free iron (56-58). $\mathrm{Cp}$ is an APR and $\mathrm{Cp}$ expression levels increase during infection, stress and inflammation (59). Cp also possesses antioxidant properties and functions in the removal of free radicals such as $\mathrm{H}_{2} \mathrm{O}_{2}$ during wound healing, collagen formation and the maturation phase which brings about extracellular matrix remodeling and resolution of the granulation of tissue $(60,61)$. However, studies have shown that $\mathrm{Cp}$ can also act as a pro-oxidant by promoting the oxidation of low density lipoprotein $(62,63)$.

al-acid glycoprotein (AGP). AGP is an APR which stabilizes the biological activity of plasminogen activator inhibitor-1, preventing platelet aggregation (64), and is present in the plasma of healthy humans at concentrations of $0.6-1.2 \mathrm{mg} / \mathrm{ml}(65)$. However, these expression levels increase 2-7-fold during an APR $(53,66)$. AGP expression in the liver is induced by activation of IL-1 $\beta$, IL- 6 and TNF- $\alpha$, and is inhibited by growth hormone $(67,68)$. AGP is considered a natural anti-inflammatory agent with respect to its anti-neutrophilic activity. For example, AGP modulates neutrophil chemotactic migration and superoxide generation in a concentration-dependent manner assisting in the re-establishment of systemic homeostasis following an infection $(59,69,70)$. AGP also inhibits monocyte chemotaxis and cellular leakage caused by histamine and bradykinin levels which are reduced by AGP, and additionally, AGP reduced the synthesis of soluble TNF $\alpha$ receptor leading to an inhibition of the inflammatory process (70). Meanwhile, AGP induces IL-1 receptor antagonism expressed on peripheral blood monocytes (71-73).

$\alpha-1$ antitrypsin $(A A T)$. AAT is the most abundant serine protease inhibitor in human blood (65). AAT is present in bodily fluids, including the saliva, tears, urine, bile and circulating blood. AAT consists of a single polypeptide chain made of 394 amino acid residues containing one free cysteine residue and three asparagine-linked carbohydrate side-chains. AAT aids in the elimination of acute inflammation, tissue proteolytic damage by neutrophil elastase in the lungs and inhibits lipopolysaccharides and the release of inflammatory mediators such as TNF- $\alpha$ and IL-1 $\beta(65,74,75)$. AAT is synthesized in the liver but is also produced by other blood cells such as monocytes, macrophages, pulmonary alveolar cells and by intestinal and corneal epithelium $(65,74,75)$. Synthesis of AAT occurs at a rate of $34 \mathrm{mg} / \mathrm{kg}$ and the protein clearance rate (half-life) is 3-5 days. As a result, high plasma concentrations of AAT usually range from $0.9-2 \mathrm{mg} / \mathrm{ml}$ in healthy individuals (76-80). During an inflammatory response, local AAT synthesis results in the invasion of inflammatory cells followed by an acute rise in AAT expression levels by as much as 11-fold (81).

Lactoferrin $(\mathrm{Lf})$. Lf is a multifunctional $80 \mathrm{kDa}$ glycoprotein which binds to $\mathrm{Fe}^{+}$and an innate immunity factor present in a range of secretory fluids, including mammalian exocrine breast milk, saliva, tears and mucosal secretions (82). Lf is also present in mucosal surfaces and specific leukocyte granules and it can be found in feces following release from fecal leukocytes (83). Abundant antimicrobial peptides and APPs are present in airway surface liquid. Lf is a bacteriostatic protein which chelates iron from $\mathrm{Fe}^{+}(82)$. Iron is required for bacterial cell division and for the development of biofilms, which are distinct, matrix-encased communities of bacteria, and the biofilm is protects against host defense mechanisms and antibiotics (84). LF chelation of iron occurs at a higher affinity in an acidic medium (85), therefore Lf binding to iron results in the prevention of growth and proliferation of iron dependent bacteria, donating this iron to beneficial bacteria, such as lactic acid bacteria (Lactobacillales) serves as a barrier against colonization of pathogenic bacteria on the intestinal surface thus preventing infection (84). Lf also has several other physiological roles, including stimulation of cell growth and proliferation, differentiation, development of immune competence, antifungal, antibacterial and antiviral activities, antioxidant and anti-inflammatory activity and anti-tumor activity $(82,85)$. Recombinant Lf (TLf) produced in the filamentous fungus, Aspergillus awamori, possesses the same biological activities as human lactoferrin and has been reported to lower mortality in adults with severe blood poisoning (86) and to have anticancer activities $(87,88)$. TLf and human lactoferrin (hLf) have been reported to display changes in immunogenicity and allergenicity in mice (89). Alteration of Lf glycosylation in human milk collected at different time points during lactation resulted in changes in bacterial binding to epithelial cells (89). Thus, hLf from milk and TLf may display different bioactivities. hLF is resistant to gastrointestinal tract digestion and may therefore play an important role in intestinal development during the prenatal period and infancy $(90,91)$. More importantly, Lf promotes maturation of dendritic cells and therefore may function as a natural defense in neonates against bacterial invasion (90) as neonates primarily rely on innate immunity (92).

Albumin. Human serum albumin (HSA) is a major plasma protein synthesized by the liver functioning in the transport of several endogenous ligands, including fatty acids, ions, thyroxine, bilirubin; and exogenous ligands as well as drugs, such as warfarin, diazepam, phenytoin, non-estradiol anti-inflammatory drugs and digoxin (93). Albumin is a member of the family of $\alpha$-fetoprotein, afamin (also called $\alpha$-albumin) and vitamin D binding protein $(94,95)$ and these proteins tend to be homologous, that is, all members of the albuminoid superfamily of proteins are suitably capable of ligand binding and transport, as they possess highly conserved intron/exon organization (95). HSA is the key regulator of fluid distribution between somatic regions of the body and body compartment (96). HSA functions to maintain plasma osmotic pressure and its synthesis is regulated by changes in blood osmotic pressure $(94,97,98)$.

HSA is an important biomarker of inflammation in a number of diseases, including cancer, diabetes, rheumatoid arthritis, ischemia and obesity (99-101). Low expression levels of HSA may indicate malnutrition and decrease in hemoglobin levels (99). HSA serves as a valuable cell culture medium and was an additive in the production of pharmaceutical vaccines (102). HSA has also been used for decades in the management of a range of medical and surgical problems, such as for the treatment of acute hypovolemia (surgical blood loss, trauma, or hemorrhage) due to its effect on osmotic pressure 
Table II. Acute phase reactants associated with vaccines.

\begin{tabular}{lllr}
\hline Author, year & \multicolumn{1}{c}{ Vaccine } & \multicolumn{1}{c}{ Acute phase reactant } & (Refs.) \\
\hline Louagie et al, 1993 & Hepatitis B & Haptoglobin & $(153)$ \\
Borthwick et al, 2018 & Human immunodeficiency virus core DNA & Serum amyloid & $(154)$ \\
Creech et al, 2017 & S. aureus capsular polysaccharides & Fibrinogen & $(155)$ \\
Blom et al, 1979 & Typhoid. AB.-cholera & Ceruloplasmin, $\alpha-1$ glycoprotein & $(156)$ \\
Naylor et al, 2015 & Rotavirus and poliovirus & $\alpha-1$ antitrypsin & $(157)$ \\
Hwang et al, 2005 & Bacillus Calmette-Guerin & Lactoferrin & $(158)$ \\
Carty et al, 2006 & Influenza & C-reactive protein, transthyretin & $(159)$ \\
Patel and Shah, 2015 & H1N1 influenza & Albumin & $(160)$ \\
Bos et al, 2016 & Neisseria gonorrhoeae & Transferrin & $(161)$ \\
\hline
\end{tabular}

providing an oncotic gradient favoring the entry of water from the interstitial space and thus reversing the movement of leaked fluids back into blood vessels $(103,104)$.

Transferrin (Tf). Tf is a member of the iron-binding glycoprotein family, including lactoferrin (present in intracellular compartments and secretions, such as milk), melanotransferrin (present on melanoma cells) and ovotransferrin (present in egg white of multiple species), and the metal and coordinating anion sites are well conserved in all vertebrates (93). Each of these iron-binding glycoproteins features a single iron-binding site and are monomeric proteins $76-81 \mathrm{kDa}$ in weight. Tf consists of two structurally similar lobes, namely, the $\mathrm{C}$ - and the N-lobes. Plasma transferrin provides body tissues with iron, whereas the remaining transferrin are produced locally and transport iron to restricted regions, including the testes and brain, as these two sites are relatively inaccessible to proteins in the general circulation due to the presence of highly specialized barriers (104). Liver hepatocytes are the primary sites of Tf production; however, Tf is also synthesized in other organs to a lesser extent, including the choroid plexus (105). The primary function of $\mathrm{Tf}$ is to transport iron from absorption centers in the duodenum and in white blood cell macrophages to all tissues (105). Tf also functions as a constituent of the innate immune system where its levels decrease during inflammation. The Tf receptor is a receptor for the IgA1 class of antibodies (106). Tf serves an important role in the somatic regions where erythropoiesis and active cell division occur (106). Iron-bound Tf is internalized by cells expressing specific Tf receptors by receptor-mediated endocytosis thus contributing to an environment with low free iron capable of inhibiting bacterial growth and multiplication during infection (96).

Transthyretin (TTR). TTR (previously referred to as prealbumin) is a negative APR synthesized and excreted by the kidneys and gastrointestinal tract with a half-life of 1.9 days and expression levels of TTR decrease significantly during inflammation which promotes an APR $(96,107)$. TTR is also synthesized in the choroid plexus and forms a complex molecule with retinol binding protein allowing retinol and thyroxine transport (107). This process is mediated by pro-inflammatory cytokines, such as IL-6, IL-1a and TNFa (108). It has been reported that TTR functions as a biomarker for predicting poor short-term outcome and disease severity in patients with burn injuries $(109,110)$ or respiratory failure $(111)$, and was strongly correlated with the score of sequential organ failure assessment, and low levels of TTR were associated with an increase in mortality $(112,113)$. Patients with low preoperative TTR levels $(<0.2 \mathrm{~g} / \mathrm{l})$ are prone to increased risk of postoperative infections and need longer mechanical ventilation after heart surgery (113).

\section{Vaccines and APP}

Upon vaccination and introduction of antigens into the body, macrophages and dendritic cells are stimulated, producing inflammatory cytokines and triggering APP synthesis in hepatocytes, which function nonspecifically as part of the innate immune system detecting pathogens or vaccination components (114). Vaccines have been shown to cause inflammatory responses which has a direct impact on the maintenance of homeostasis, particularly in the kidney and the liver (115). Disruption of homeostasis during APR can negatively affect the host $(3,7,16)$, for example, plasma levels of a number of microminerals, including iron, may change as they are taken up by hepatocytes and other cell types (7). As the APR increases the products of metabolism will also increase (4). The increase in the plasma proteins during APR affects the concentration of the free form of any drug administered at the time of stress, leading to drug dispersal, and variations in plasma protein concentrations during the acute phase response may result in the plasma levels of available drugs to decrease considerably whereas the total drug concentration (free and bound) will be only slightly affected, and thus the effective dose will be altered due to fluctuations in serum protein levels and decreased serum albumin expression levels $(116,117)$. Individual variation in the expression levels of APRs in response to inflammatory stimuli, such as vaccines, has been previously reported in cattle (118), mice (119) and humans (120). This difference may be due to individual differences in inflammatory genes $(120,121)$. Obesity can alter vaccination responses in mice, wherein the obesity was associated with decreased antibody production and ultimately reduced the efficacy of an influenza vaccine (122). Furthermore, decreased influenza-specific antibody levels and B-cell function in response to vaccination has also been linked to obesity in humans (123). Administration of vaccines containing foreign particles into the body triggers 
local inflammation due to an immediate change in cytokine production, which triggers the clinical symptoms associated with vaccination. Overall, a reduced response to vaccination is a likely indication of an unregulated inflammatory system which may lead to increased risk of disease as the majority of vaccines protect against infection through induction of a B-cell antibody response (124).

Pro-inflammatory cytokine IL-6 is an important regulator of inflammation and is one of the primary cytokines which stimulate APP synthesis in hepatocytes (125-127). IL-6 functions in several processes during inflammation, including chemokine production, development of B-cells and dendritic cells, secretion and maturation of antibodies, T-cell maturation, as well as linking the innate and adaptive immune responses $(128,129)$. An acute spike of anti-IL-6 was observed 5 days post vaccination in a small study of yellow fever vaccine, indicating its potential role predict vaccine-induced protection (130). Kurtz et al (131) studied the protective mechanisms of IL-6 against a Francisella tularensis live vaccine administered intradermally or intranasally to IL-6 knockout (KO) and wild type mice. The group reported a decline in SSA and Hp in IL-6 KO mice compared with wild type controls, indicating the importance of IL-6 in protection against infection.

In humans, the efficacy of the influenza vaccination has been invaluable. In one study, CRP expression levels increased by $36 \%$, further increasing to $40 \%$ above baseline at day 3 , before returning to the normal levels by day 7 following vaccination (132). In a study of patients $>65$ years old, CRP plasma concentrations spiked at 2 days post vaccination with influenza and pneumococcal vaccines as well as a combination of the two (133). Another study investigating the influenza vaccine showed that CRP expression levels post-vaccination were dependent on the dose of vaccine (134). Table II show acute phase reactants associated with vaccines.

\section{Effect of adjuvant systems on APP}

Adjuvants are compounds joined with other constituents in vaccine formulations (135) where multiple immunostimulants are combined with adjuvant systems to enhance antibody production and adaptive immune responses to vaccination (136). Adjuvant components regulate and improve the specificity of the immune system, thus aiming to optimize the immune response to vaccination (136). To date, there have been at least six novel adjuvants approved for use as vaccine components in the last 20 years $(135,136)$. Adjuvant systems can be useful when strong $\mathrm{T}$ cell responses are required to protect against complex pathogens formed of several different types of antigens, chronic infections, or in immunocompromised populations such as the elderly or neonates $(137,138)$. A previous study on the effects of adjuvants in rabbits indicated that CRP and fibrinogen expression levels were increased following the administration of adjuvant systems AS01, AS03, AS15 and DTPw (139). The increase in CRP levels increased 9-26-fold after injection of AS01, AS03, or AS15. Comparable effects have also been shown in humans (140). However, the use of other adjuvants such as aluminum phosphate and aluminum hydroxide did not affect CRP expression levels in the elderly or in the young following a diphtheria-tetanus-poliomyelitis-typhoid vaccine (141), influenza vaccine (142) or yellow fever vaccine $(120,130)$. Overall, these studies indicate the efficacy of these adjuvant systems in stimulating the adaptive immune response.

\section{Conclusion}

APRs a group of 11 key proteins, eight of which are positive and three are negative proteins. During infection, the liver hepatocytes respond by producing a large number of APRs. Upon vaccination, an acute-phase protein reaction may develop which is a part of the innate immune system. Vaccination has also been demonstrated to cause an inflammatory response, which results in homeostatic changes including changes in renal and liver functions. Changes in APR expression levels in response to an inflammatory stimulus may vary across individuals due to genetic, nutritional, age, or other health-associated factors. The health and nutritional status of the individual may affect the response to a given vaccine due to the inflammatory condition. For example, IL-6 (an inflammatory key mediator and regulator of the majority of APRs) functions in the acute-phase protein response in the innate and adaptive branches of the immune system. CRP, as a prototypical APP, is synthesized in response to pro-inflammatory cytokine signals and CRP expression levels increase in innate immune responses to infection or to injury. Further investigations into the relationships between vaccination and the effect on CRP and other APRs may help clarify the mechanisms by which beneficial and harmful inflammatory responses affect health and influence the immune response.

\section{Acknowledgements}

Not applicable.

\section{Funding}

No funding was received.

\section{Availability of data and materials}

Not applicable.

\section{Authors' contributions}

RHK and NAH wrote the manuscript, edited and critically reviewed the manuscript. Both authors read and approved the final version of the manuscript.

\section{Ethics approval and consent to participate}

Not applicable.

\section{Patient consent for publication}

Not applicable.

\section{Competing interests}

This article reflects the views of the authors and should not be construed to represent the FDA's views or policies. 
Dr Humadi's contributions are an informal communication and represent his own best judgement. These comments do not bind or obligate FDA.

\section{References}

1. Deans $C$ and Wigmore SJ: Systemic inflammation, cachexia and prognosis in patients with cancer. Curr Opin Clin Nutr Metab Care 8: 265-269, 2005.

2. Ridker PM: Inflammatory biomarkers and risks of myocardial infarction, stroke, diabetes, and total mortality: Implications for longevity. Nutr Rev 65 (Suppl): S253-S259, 2007.

3. Cray C, Zaias $\mathrm{J}$ and Altman NH: Acute phase response in animals: A review. Comp Med 59: 517-526, 2009.

4. Boosalis MG, Snowdon DA, Tully CL and Gross MD: Acute phase response and plasma carotenoid concentrations in older women: Findings from the nun study. Nutrition 12: 475-478, 1996.

5. Mackiewicz A: Acute phase proteins and transformed cells. Int Rev Cytol 170: 225-300, 1997.

6. Koj A: Termination of acute-phase response: Role of some cytokines and anti-inflammatory drugs. Gen Pharmacol 31: 9-18, 1998.

7. Ceron JJ, Eckersall PD and Martynez-Subiela S: Acute phase proteins in dogs and cats: Current knowledge and future perspectives. Vet Clin Pathol 34: 85-99, 2005.

8. Gómez-Laguna J, Salguero FJ, Pallarés FJ, Rodríguez-Gómez IM, Barranco I and Carrasco L: Acute phase proteins as biomarkers in animal health and welfare. In: Acute Phase Proteins As Early Non-Specific Biomarkers of Human and Veterinary Diseases. Veas F (ed). InTech, pp259-298, 2011

9. Sharpe-Timms KL, Nabli H, Zimmer RL, Birt JA and Davis JW: Inflammatory cytokines differentially up-regulate human endometrial haptoglobin production in women with endometriosis Hum Reprod 25: 1241-1250, 2010.

10. Suk HJ, Ridker PM, Cook NR and Zee RY: Relation of polymorphism within the C-reactive protein gene and plasma CRP levels. Atherosclerosis 178: 139-145, 2005.

11. Macleod CM and Avery OT: The occurrence during acute infections of a protein not normally present in the blood: II. Isolation and properties of the reactive protein. J Exp Med 73: 183-190, 1941

12. Ballou SP and Kushner I: C-reactive protein and the acute phase response. Adv Intern Med 37: 313-336, 1992.

13. Anderson HC and McCarty M: The occurrence in the rabbit of an acute phase protein analogous to human $\mathrm{C}$ reactive protein J Exp Med 93: 25-36, 1951.

14. Mold C, Rodriguez W, Rodic-Polic B and Du Clos TW: C-reactive protein mediates protection from lipopolysaccharide through interactions with Fc gamma R. J Immunol 169: 7019-7025, 2002

15. Volanakis JE and Kaplan MH: Specificity of C-reactive protein for choline phosphate residues of pneumococcal C-polysaccharide. Proc Soc Exp Biol Med 136: 612-614, 1971.

16. Gabay $\mathrm{C}$ and Kushner I: Acute-phase proteins and other systemic responses to inflammation. N Engl J Med 340: 448-454, 1999.

17. Volanakis JE: Acute phase proteins in rheumatic disease. In: Arthritis and allied conditions: A textbook of rheumatology. Koopman WJ (ed). 13 edition. Williams \& Wilkins, Baltimore, MD, pp505-514, 1997.

18. Rao AK, Chouhan V, Chen X, Sun L and Boden G: Activation of the tissue factor pathway of blood coagulation during prolonged hyperglycemia in young healthy men. Diabetes 48: 1156-1161, 1999.

19. Stegenga ME, van der Crabben SN, Levi M, de Vos AF, Tanck MW, Sauerwein HP and van der Poll T: Hyperglycemia stimulates coagulation, whereas hyperinsulinemia impairs fibrinolysis in healthy humans. Diabetes 55: 1807-1812, 2006.

20. Pepys MB and Hirschfield GM: C-reactive protein: A critical update. J Clin Invest 111: 1805-1812, 2003.

21. Falsey AR, Walsh EE, Francis CW, Looney RJ, Kolassa JE, Hall WJ and Abraham GN: Response of C-reactive protein and serum amyloid A to influenza A infection in older adults. J Infect Dis 183: 995-999, 2001.

22. Woloshin S and Schwartz LM: Distribution of C-reactive protein values in the United States. N Engl J Med 352: 1611-1613, 2005.

23. Yen-Watson B and Kushner I: Rabbit CRP response to endotoxin administration: Dose-response relationship and kinetics. Proc Soc Exp Biol Med 146: 1132-1136, 1974.
24. Langlois MR and Delanghe JR: Biological and clinical significance of haptoglobin polymorphism in humans. Clin Chem 42 : 1589-1600, 1996.

25. Bowman BH and Kurosky A: Haptoglobin: The evolutionary product of duplication, unequal crossing over, and point mutation. Adv Hum Genet 12: 189-261, 453-184, 1982.

26. Alayash AI: Redox biology of blood. Antioxid Redox Signal 6: 941-943, 2004

27. Eklund KK, Niemi K and Kovanen PT: Immune functions of serum amyloid A. Crit Rev Immunol 32: 335-348, 2012.

28. Minneci PC, Deans KJ, Zhi H, Yuen PS, Star RA, Banks SM, Schechter AN, Natanson C, Gladwin MT and Solomon SB: Hemolysis-associated endothelial dysfunction mediated by accelerated NO inactivation by decompartmentalized oxyhemoglobin. J Clin Invest 115: 3409-3417, 2005.

29. Gilstad CW: Anaphylactic transfusion reactions. Curr Opin Hematol 10: 419-423, 2003.

30. Larsen K, Macleod D, Nihlberg K, Gurcan E, Bjermer L, Marko-Varga G and Westergren-Thorsson G: Specific haptoglobin expression in bronchoalveolar lavage during differentiation of circulating fibroblast progenitor cells in mild asthma. J Proteome Res 5: 1479-1483, 2006.

31. Shimada E, Tadokoro K, Watanabe Y, Ikeda K, Niihara H, Maeda I, Isa K, Moriya S, Ashida T, Mitsunaga S, et al: Anaphylactic transfusion reactions in haptoglobin-deficient patients with IgE and IgG haptoglobin antibodies. Transfusion 42: 766-773, 2002.

32. Arredouani M, Matthijs P, Van Hoeyveld E, Kasran A, Baumann H, Ceuppens JL and Stevens E: Haptoglobin directly affects $\mathrm{T}$ cells and suppresses $\mathrm{T}$ helper cell type 2 cytokine release. Immunology 108: 144-151, 2003.

33. Saeed SA, Ahmad N and Ahmed S: Dual inhibition of cyclooxygenase and lipoxygenase by human haptoglobin: Its polymorphism and relation to hemoglobin binding. Biochem Biophys Res Commun 353: 915-920, 2007.

34. Pepys MB, Dash AC, Markham RE, Thomas HC, Williams BD and Petrie A: Comparative clinical study of protein SAP (amyloid P component) and C-reactive protein in serum. Clin Exp Immunol 32: 119-124, 1978.

35. Derebe MG, Zlatkov CM, Gattu S, Ruhn KA, Vaishnava S, Diehl GE, MacMillan JB, Williams NS and Hooper LV: Serum amyloid $\mathrm{A}$ is a retinol binding protein that transports retinol during bacterial infection. Elife 3: e03206, 2014

36. Bottazzi B, Doni A, Garlanda C and Mantovani A: An integrated view of humoral innate immunity: Pentraxins as a paradigm. Annu Rev Immunol 28: 157-183, 2010.

37. Hind CR, Collins PM, Renn D, Cook RB, Caspi D, Baltz ML and Pepys MB: Binding specificity of serum amyloid P component for the pyruvate acetal of galactose. J Exp Med 159: 1058-1069, 1984.

38. Loveless RW, Floyd-O'Sullivan G, Raynes JG, Yuen CT and Feizi T: Human serum amyloid $P$ is a multispecific adhesive protein whose ligands include 6-phosphorylated mannose and the 3-sulphated saccharides galactose, $\mathrm{N}$-acetylgalactosamine and glucuronic acid. EMBO J 11: 813-819, 1992.

39. Familian A, Zwart B, Huisman HG, Rensink I, Roem D, Hordijk PL, Aarden LA and Hack CE: Chromatin-independent binding of serum amyloid $\mathrm{P}$ component to apoptotic cells. J Immunol 167: 647-654, 2001.

40. Husby G, Marhaug G, Dowton B, Sletten K and Sipe JD: Serum amyloid A (SAA): Biochemistry, genetics and the pathogenesis of AA amyloidosis. Int J Exu Clin Invest 1: 119-137, 1994.

41. Wang S, Murphy CL, Kestler D, Macy SD, Williams TK, Weiss DT and Solomon A: SAA4-related AA amyloidosis. In: XIth International Symposium on Amyloidosis. CRC Press, Boca Raton, FL, 2008.

42. Eriksen $\mathrm{N}$ and Benditt EP: Isolation and characterization of the amyloid-related apoprotein (SAA) from human high density lipoprotein. Proc Natl Acad Sci USA 77: 6860-6864, 1980.

43. Levy JH, Szlam F, Tanaka KA and Sniecienski RM: Fibrinogen and hemostasis: A primary hemostatic target for the management of acquired bleeding. Anesth Analg 114: 261-274, 2012.

44. Jennewein C, Tran N, Paulus P, Ellinghaus P, Eble JA and Zacharowski K: Novel aspects of fibrin(ogen) fragments during inflammation. Mol Med 17: 568-573, 2011.

45. Mosesson MW: Fibrinogen and fibrin structure and functions. J Thromb Haemost 3: 1894-1904, 2005.

46. Meyer MA, Ostrowski SR, Windelov NA and Johansson PI: Fibrinogen concentrates for bleeding trauma patients: What is the evidence? Vox Sang 101: 185-190, 2011 
47. Furie B and Furie BC: The molecular basis of blood coagulation. Cell 53: 505-518, 1988.

48. Colvin RB, Johnson RA, Mihm MC Jr and Dvorak HF: Role of the clotting system in cell-mediated hypersensitivity. I. Fibrin deposition in delayed skin reactions in man. J Exp Med 138: 686-698, 1973.

49. Labarrere CA, Nelson DR and Faulk WP: Myocardial fibrin deposits in the first month after transplantation predict subsequent coronary artery disease and graft failure in cardiac allograft recipients. Am J Med 105: 207-213, 1998.

50. Ryden L and Eaker D: Identification of the thiol groups in human ceruloplasmin. Eur J Biochem 132: 241-247, 1983.

51. Jamieson GA: Studies on Glycoproteins. I. The carbohydrate portion of human ceruloplasmin. J Biol Chem 240: 2019-2027, 1965.

52. Harris ZL, Klomp LW and Gitlin JD: Aceruloplasminemia: An inherited neurodegenerative disease with impairment of iron homeostasis. Am J Clin Nutr 67 (5 Suppl): 972S-977S, 1998.

53. Colombo S, Buclin T, Decosterd LA, Telenti A, Furrer H, Lee BL, Biollaz J and Eap CB; Swiss HIV Cohort Study: Orosomucoid (alpha1-acid glycoprotein) plasma concentration and genetic variants: Effects on human immunodeficiency virus protease inhibitor clearance and cellular accumulation. Clin Pharmacol Ther 80: 307-318, 2006.

54. Osaki S, Johnson DA and Frieden E: The possible significance of the ferrous oxidase activity of ceruloplasmin in normal human serum. J Biol Chem 241: 2746-2751, 1966.

55. Osaki S, Johnson DA and Frieden E: The mobilization of iron from the perfused mammalian liver by a serum copper enzyme, ferroxidase I. J Biol Chem 246: 3018-3023, 1971.

56. Attieh ZK, Mukhopadhyay CK, Seshadri V, Tripoulas NA and Fox PL: Ceruloplasmin ferroxidase activity stimulates cellular iron uptake by a trivalent cation-specific transport mechanism. J Biol Chem 274: 1116-1123, 1999.

57. Harris ZL, Takahashi Y, Miyajima H, Serizawa M, MacGillivray RT and Gitlin JD: Aceruloplasminemia: Molecular characterization of this disorder of iron metabolism. Proc Natl Acad Sci USA 92: 2539-2543, 1995.

58. Lahey ME, Gubler CJ, Chase MS, Cartwright GE and Wintrobe MM: Studies on copper metabolism. II. Hematologic manifestations of copper deficiency in swine. Blood 7: 1053-1074, 1952.

59. Hochepied T, Berger FG, Baumann H and Libert C: Alpha(1)-acid glycoprotein: An acute phase protein with inflammatory and immunomodulating properties. Cytokine Growth Factor Rev 14 $25-34,2003$.

60. Giurgea N, Constantinescu MI, Stanciu R, Suciu S and Muresan A: Ceruloplasmin-acute-phase reactant or endogenous antioxidant? The case of cardiovascular disease. Med Sci Monit 11: RA48-RA51, 2005.

61. Gutteridge JM: Caeruloplasmin: A plasma protein, enzyme, and antioxidant. Ann Clin Biochem 15: 293-296, 1978.

62. Mukhopadhyay CK, Ehrenwald E and Fox PL: Ceruloplasmin enhances smooth muscle cell- and endothelial cell-mediated low density lipoprotein oxidation by a superoxide-dependent mechanism. J Biol Chem 271: 14773-14778, 1996

63. Mukhopadhyay CK, Mazumder B, Lindley PF and Fox PL: Identification of the prooxidant site of human ceruloplasmin: A model for oxidative damage by copper bound to protein surfaces. Proc Natl Acad Sci USA 94: 11546-11551, 1997.

64. Smolarczyk K, Gils A, Boncela J, Declerck PJ and Cierniewski CS Function-stabilizing mechanism of plasminogen activator inhibitor type 1 induced upon binding to alpha1-acid glycoprotein. Biochemistry 44: 12384-12390, 2005.

65. Geboes K, Ray MB, Rutgeerts P, Callea F, Desmet VJ and Vantrappen G: Morphological identification of alpha-I-antitrypsin in the human small intestine. Histopathology 6: 55-60, 1982.

66. Kremer JM, Wilting J and Janssen LH: Drug binding to human alpha-1-acid glycoprotein in health and disease. Pharmacol Rev 40: 1-47, 1988.

67. Barraud B, Balavoine S, Feldmann G and Lardeux B: Effects of insulin, dexamethasone and cytokines on alpha 1-acid glycoprotein gene expression in primary cultures of normal rat hepatocytes. Inflammation 20: 191-202, 1996.

68. Mejdoubi N, Henriques C, Bui E, Durand G, Lardeux B and Porquet D: Growth hormone inhibits rat liver alpha-1-acid glycoprotein gene expression in vivo and in vitro. Hepatology 29: $186-194,1999$
69. Costello MJ, Gewurz H and Siegel JN: Inhibition of neutrophil activation by alpha1-acid glycoprotein. Clin Exp Immunol 55: 465-472, 1984

70. Laine E, Couderc R, Roch-Arveiller M, Vasson MP, Giroud JP and Raichvarg D: Modulation of human polymorphonuclear neutrophil functions by alpha 1-acid glycoprotein. Inflammation 14: $1-9,1990$.

71. Tilg H, Vannier E, Vachino G, Dinarello CA and Mier JW: Antiinflammatory properties of hepatic acute phase proteins: Preferential induction of interleukin 1 (IL-1) receptor antagonist over IL-1 beta synthesis by human peripheral blood mononuclear cells. J Exp Med 178: 1629-1636, 1993.

72. Samak R, Edelstein R and Israel L: Immunosuppressive effect of acute-phase reactant proteins in vitro and its relevance to cancer. Cancer Immunol Immunother 13: 38-43, 1982.

73. Muchitsch EM, Teschner W, Linnau Y and Pichler L: In vivo effect of alpha 1-acid glycoprotein on experimentally enhanced capillary permeability in guinea-pig skin. Arch Int Pharmacodyn Ther 331: 313-321, 1996.

74. Perlmutter DH, Kay RM, Cole FS, Rossing TH, Van Thiel D and Colten HR: The cellular defect in alpha 1-proteinase inhibitor (alpha 1-PI) deficiency is expressed in human monocytes and in Xenopus oocytes injected with human liver mRNA. Proc Natl Acad Sci USA 82: 6918-6921, 1985.

75. Ray MB, Geboes K, Callea F and Desmet VJ: Alpha-1-antitrypsin immunoreactivity in gastric carcinoid. Histopathology 6: 289-297, 1982.

76. Berman MB, Barber JC, Talamo RC and Langley CE: Corneal ulceration and the serum antiproteases. I. Alpha 1-antitrypsin. Invest Ophthalmol 12: 759-770, 1973.

77. Chowanadisai $\mathrm{W}$ and Lonnerdal B: Alpha(1)-antitrypsin and antichymotrypsin in human milk: Origin, concentrations, and stability. Am J Clin Nutr 76: 828-833, 2002.

78. Huang CM: Comparative proteomic analysis of human whole saliva. Arch Oral Biol 49: 951-962, 2004.

79. Janciauskiene S,TothE,Sahlin S andEriksson S:Immunochemical and functional properties of biliary alpha-1-antitrypsin. Scand J Clin Lab Invest 56: 597-608, 1996.

80. Poortmans J and Jeanloz RW: Quantitative immunological determination of 12 plasma proteins excreted in human urine collected before and after exercise. J Clin Invest 47: 386-393, 1968.

81. Boskovic G and Twining SS: Retinol and retinaldehyde specifically increase alpha1-proteinase inhibitor in the human cornea. Biochem J 322: 751-756, 1997.

82. Lonnerdal B and Iyer S: Lactoferrin: Molecular structure and biological function. Annu Rev Nutr 15: 93-110, 1995.

83. Garcia-Montoya IA, Cendon TS, Arevalo-Gallegos S and Rascon-Cruz Q: Lactoferrin a multiple bioactive protein: An overview. Biochim Biophys Acta 1820: 226-236, 2012.

84. Singh PK, Parsek MR, Greenberg EP and Welsh MJ: A component of innate immunity prevents bacterial biofilm development. Nature 417: 552-555, 2002.

85. Vogel HJ: Lactoferrin, a bird's eye view. Biochem Cell Biol 90: 233-244, 2012

86. Guntupalli K, Dean N, Morris PE, Bandi V, Margolis B, Rivers E, Levy M, Lodato RF, Ismail PM, Reese A, et al: A phase 2 randomized, double-blind, placebo-controlled study of the safety and efficacy of talactoferrin in patients with severe sepsis. Crit Care Med 41: 706-716, 2013.

87. Digumarti R, Wang Y, Raman G, Doval DC, Advani SH, Julka PK, Parikh PM, Patil S, Nag S, Madhavan J, et al: A randomized, double-blind, placebo-controlled, phase II study of oral talactoferrin in combination with carboplatin and paclitaxel in previously untreated locally advanced or metastatic non-small cell lung cancer. J Thorac Oncol 6: 1098-1103, 2011.

88. Parikh PM, Vaid A, Advani SH, Digumarti R, Madhavan J, Nag S, Bapna A, Sekhon JS, Patil S, Ismail PM, et al: Randomized, double-blind, placebo-controlled phase II study of single-agent oral talactoferrin in patients with locally advanced or metastatic non-small-cell lung cancer that progressed after chemotherapy. J Clin Oncol 29: 4129-4136, 2011.

89. Almond RJ, Flanagan BF, Antonopoulos A, Haslam SM, Dell A, Kimber I and Dearman RJ: Differential immunogenicity and allergenicity of native and recombinant human lactoferrins: Role of glycosylation. Eur J Immunol 43: 170-181, 2013

90. Lonnerdal B, Jiang R and Du X: Bovine lactoferrin can be taken up by the human intestinal lactoferrin receptor and exert bioactivities. J Pediatr Gastroenterol Nutr 53: 606-614, 2011.

91. Davidson LA and Lonnerdal B: Persistence of human milk proteins in the breast-fed infant. Acta Paediatr Scand 76: 733-740, 1987. 
92. Wynn JL and Levy O: Role of innate host defenses in susceptibility to early-onset neonatal sepsis. Clin Perinatol 37: 307-337, 2010.

93. Lambert LA: Molecular evolution of the transferrin family and associated receptors. Biochim Biophys Acta 1820: 244-255, 2012.

94. Peters T Jr: All about albumin. Biochemistry, Genetics and Medical Applications. Academic Press, Inc., San Diego, CA, 1996

95. Fasano M, Fanali G, Leboffe L and Ascenzi P: Heme binding to albuminoid proteins is the result of recent evolution. IUBMB Life 59: 436-440, 2007.

96. Aisen P: Transferrin receptor 1. Int J Biochem Cell Biol 36 : 2137-2143, 2004.

97. Evans TW: Review article: Albumin as a drug-biological effects of albumin unrelated to oncotic pressure. Aliment Pharmaco Ther 16 (Suppl 5): S6-S11, 2002.

98. Mendez CM, McClain CJ and Marsano LS: Albumin therapy in clinical practice. Nutr Clin Pract 20: 314-320, 2005.

99. Gupta D and Lis CG: Pretreatment serum albumin as a predictor of cancer survival: A systematic review of the epidemiological literature. Nutr J 9: 69, 2010

100. Koga M and Kasayama S: Clinical impact of glycated albumin as another glycemic control marker. Endocr J 57: 751-762, 2010

101. Sbarouni E, Georgiadou P and Voudris V: Ischemia modified albumin changes-review and clinical implications. Clin Chem Lab Med 49: 177-184, 2011.

102. Marth E and Kleinhappl B: Albumin is a necessary stabilizer of TBE-vaccine to avoid fever in children after vaccination. Vaccine 20: 532-537, 2001

103. Haynes GR, Navickis RJ and Wilkes MM: Albumin administration-what is the evidence of clinical benefit? A systematic review of randomized controlled trials. Eur J Anaesthesiol 20 771-793, 2003

104. Alderson P, Bunn F, Lefebvre C, Li WP, Li L, Roberts I and Schierhout G; Albumin Reviewers: Human albumin solution for resuscitation and volume expansion in critically ill patients. Cochrane Database Syst Rev 2004: CD001208, 2004.

105. Idzerda RL, Huebers H, Finch CA and McKnight GS: Rat transferrin gene expression: Tissue-specific regulation by iron deficiency. Proc Natl Acad Sci USA 83: 3723-3727, 1986.

106. Macedo MF and de Sousa M: Transferrin and the transferrin receptor: Of magic bullets and other concerns. Inflamm Allergy Drug Targets 7: 41-52, 2008

107. Ingenbleek Y and Young V: Transthyretin (prealbumin) in health and disease: Nutritional implications. Annu Rev Nutr 14: 495-533, 1994.

108. Ballmer PE: Causes and mechanisms of hypoalbuminaemia. Clin Nutr 20: 271-273, 2001.

109. Cynober L, Prugnaud O, Lioret N, Duchemin C, Saizy R and Giboudeau J: Serum transthyretin levels in patients with burn injury. Surgery 109: 640-644, 1991.

110. Yang HT, Yim H, Cho YS, Kim D, Hur J, Kim JH, Lee JW, Lee YK, Lee J, Han SW and Chun W: Serum transthyretin level is associated with clinical severity rather than nutrition status in massively burned patients. JPEN J Parenter Enteral Nutr 38: 966-972, 2014.

111. Le Bricon T, Guidet B, Coudray-Lucas C, Staikowsky F, Gabillet JM, Offenstadt G, Giboudeau J and Cynober L: Biochemical assessment of nutritional status in patients with chronic obstructive pulmonary disease and acute respiratory failure on admission to an intensive care unit. Clin Nutr 13 : 98-104, 1994

112. Germano Borges de Oliveira Nascimento Freitas R; Negrao Nogueira RJ and Hessel G: Protein needs of Critically Ill patients receiving parenteral nutrition. Nutr Hosp 32: 250-255, 2015

113. Yu PJ, Cassiere HA, Dellis SL, Manetta F, Kohn N and Hartman AR: Impact of preoperative prealbumin on outcomes after cardiac surgery. JPEN J Parenter Enteral Nutr 39: 870-874, 2015.

114. Alsemgeest SP, Kalsbeek HC, Wensing T, Koeman JP, van Ederen $\mathrm{AM}$ and Gruys E: Concentrations of serum amyloid-A (SAA) and haptoglobin (HP) as parameters of inflammatory diseases in cattle. Vet Q 16: 21-23, 1994.

115. Mills PC, Auer DE, Kramer H, Barry D and Ng JC: Effects of inflammation-associated acute-phase response on hepatic and renal indices in the horse. Aust Vet J 76: 187-194, 1998.

116. Mills PC, Ng JC and Auer DE: The effect of inflammation on the disposition of phenylbutazone in thoroughbred horses. J Vet Pharmacol Ther 19: 475-481, 1996.
117. Mills PC, Ng JC and Auer DE: The effect of the acute-phase response on in vitro drug metabolism and plasma protein binding in the horse. Vet Res Commun 21: 361-368, 1997.

118. Jacobsen S, Andersen PH, Toelboell T and Heegaard PM: Dose dependency and individual variability of the lipopolysaccharide-induced bovine acute phase protein response. J Dairy Sci 87: 3330-3339, 2004

119. Araujo LM, Ribeiro OG, Siqueira M, De Franco M, Starobinas N, Massa S, Cabrera WH, Mouton D, Seman M and Ibañez OM Innate resistance to infection by intracellular bacterial pathogens differs in mice selected for maximal or minimal acute inflammatory response. Eur J Immunol 28: 2913-2920, 1998

120. Verschuur M, van der Beek MT, Tak HS, Visser LG and de Maat MP: Interindividual variation in the response by fibrinogen, C-reactive protein and interleukin- 6 to yellow fever vaccination. Blood Coagul Fibrinolysis 15: 399-404, 2004

121. Elsasser TH, Blum JW and Kahl S: Characterization of calves exhibiting a novel inheritable TNF-alpha hyperresponsiveness to endotoxin: Associations with increased pathophysiological complications. J Appl Physiol (1985) 98: 2045-2055, 2005.

122. Park HL, Shim SH, Lee EY, Cho W, Park S, Jeon HJ, Ahn SY, Kim $\mathrm{H}$ and Nam JH: Obesity-induced chronic inflammation is associated with the reduced efficacy of influenza vaccine. Hum Vaccin Immunother 10: 1181-1186, 2014.

123. Frasca D, Ferracci F, Diaz A, Romero M, Lechner S and Blomberg BB: Obesity decreases B cell responses in young and elderly individuals. Obesity (Silver Spring) 24: 615-625, 2016.

124. Lisciandro JG and van den Biggelaar AH: Neonatal immune function and inflammatory illnesses in later life: Lessons to be learnt from the developing world? Clin Exp Allergy 40: 1719-1731, 2010.

125. Eckersall PD, Lawson FP, Bence L, Waterston MM, Lang TL, Donachie W and Fontaine MC: Acute phase protein response in an experimental model of ovine caseous lymphadenitis. BMC Vet Res 3: 35, 2007.

126. EL-Deeb WM and El-Bahr SM: Selected biochemical indicators of equine rhabdomyolysis in Arabian horses: Acute phase proteins and trace elements. Equine Vet Sci 34: 484-488, 2014.

127. EL-Deeb WM, El-Moslemany AM and Salem MA: Cardiac troponin I and immune inflammatory response in horses with strangles. Equine Vet Sci 51: 18-23, 2017.

128. Jones SA: Directing transition from innate to acquired immunity: Defining a role for IL-6. J Immunol 175: 3463-3468, 2005

129. Chomarat P, Banchereau J, Davoust J and Palucka AK: IL-6 switches the differentiation of monocytes from dendritic cells to macrophages. Nat Immunol 1: 510-514, 2000.

130. van der Beek MT, Visser LG and de Maat MP: Yellow fever vaccination as a model to study the response to stimulation of the inflammation system. Vascul Pharmacol 39: 117-121, 2002.

131. Kurtz SL, Foreman O, Bosio CM, Anver MR and Elkins KL: Interleukin-6 is essential for primary resistance to Francisella tularensis live vaccine strain infection. Infect Immun 81: 585-597, 2013

132. Tsai MY, Hanson NQ, Straka RJ, Hoke TR, Ordovas JM, Peacock JM, Arends VL and Arnett DK: Effect of influenza vaccine on markers of inflammation and lipid profile. J Lab Clin Med 145: 323-327, 2005

133. Posthouwer D, Voorbij HA, Grobbee DE, Numans ME and van der Bom JG: Influenza and pneumococcal vaccination as a model to assess C-reactive protein response to mild inflammation. Vaccine 23: 362-365, 2004

134. Treanor JJ, Taylor DN, Tussey L, Hay C, Nolan C, Fitzgerald T, Liu G, Kavita U, Song L, Dark I and Shaw A: Safety and immunogenicity of a recombinant hemagglutinin influenza-flagellin fusion vaccine (VAX125) in healthy young adults. Vaccine 28 8268-8274, 2010.

135. Njoroge L, Khayata M, Zacharias M and ElAmm C: Acute myocarditis following influenza vaccine in a heart transplant patient. J Cardiac Failure 24 (Suppl): S45-S46, 2018.

136. Garcon N, Leroux-Roels $\mathrm{G}$ and Cheng W: Vaccine adjuvants. In: Understanding Modern Vaccines: Perspectives in Vaccinology: Elsevier, pp89-113, 2011.

137. Mutwiri G, Gerdts V, van Drunen Littel-van den Hurk S, Auray G, Eng N, Garlapati S, Babiuk LA and Potter A: Combination adjuvants: The next generation of adjuvants? Expert Rev Vaccines 10: 95-107, 2011.

138. Singh M, Ugozzoli M, Kazzaz J, Chesko J, Soenawan E, Mannucci D, Titta F, Contorni M, Volpini G, Del Guidice G and O'Hagan DT: A preliminary evaluation of alternative adjuvants to alum using a range of established and new generation vaccine antigens. Vaccine 24: 1680-1686, 2006. 
139. Leroux-Roels G: Unmet needs in modern vaccinology: Adjuvants to improve the immune response. Vaccine 28 (Suppl 3): C25-C36, 2010

140. Destexhe E, Prinsen MK, van Schöll I, Kuper CF, Garçon N, Veenstra $\mathrm{S}$ and Segal L: Evaluation of C-reactive protein as an inflammatory biomarker in rabbits for vaccine nonclinical safety studies. J Pharmacol Toxicol Methods 68: 367-373, 2013.

141. El Yousfi M, Mercier S, Breuillé D, Denis P, Papet I, Mirand PP and Obled C: The inflammatory response to vaccination is altered in the elderly. Mech Ageing Dev 126: 874-881, 2005

142. Liuba P, Aburawi EH, Pesonen E, Andersson S, Truedsson L, Ylä-Herttuala $S$ and Holmberg L: Residual adverse changes in arterial endothelial function and LDL oxidation after a mild systemic inflammation induced by influenza vaccination. Ann Med 39: 392-399, 2007.

143. He R, Shepard LW, Chen J, Pan ZK and Ye RD: Serum amyloid $\mathrm{A}$ is an endogenous ligand that differentially induces IL-12 and IL-23. J Immunol 177: 4072-4079, 2006.

144. Lu P, Liu J and Pang X: Pravastatin inhibits fibrinogen- and FDP-induced inflammatory response via reducing the production of IL-6, TNF-alpha and iNOS in vascular smooth muscle cells. Mol Med Rep 12: 6145-6151, 2015.

145. Lazzaro M, Bettegazzi B, Barbariga M, Codazzi F, Zacchetti D and Alessio M: Ceruloplasmin potentiates nitric oxide synthase activity and cytokine secretion in activated microglia. J Neuroinflammation 11: 164, 2014

146. Martinez Cordero E, Gonzalez MM, Aguilar LD, Orozco EH and Hernandez Pando R: Alpha-1-acid glycoprotein, its local production and immunopathological participation in experimental pulmonary tuberculosis. Tuberculosis (Edinb) 88 203-211, 2008.

147. de Serres F and Blanco I: Role of alpha-1 antitrypsin in human health and disease. J Intern Med 276: 311-335, 2014.

148. Haversen L, Ohlsson BG, Hahn-Zoric M, Hanson LA and Mattsby-Baltzer I: Lactoferrin down-regulates the LPS-induced cytokine production in monocytic cells via NF-kappa B. Cell Immunol 220: 83-95, 2002.

149. Du Clos TW: Function of C-reactive protein. Ann Med 32: 274-278, 2000.

150. Spadaro M, Montone M, Arigoni M, Cantarella D, Forni G, Pericle F, Pascolo S, Calogero RA and Cavallo F: Recombinant human lactoferrin induces human and mouse dendritic cell maturation via Toll-like receptors 2 and 4. FASEB J 28: 416-429, 2014

151. Feelders RA, Vreugdenhil G,Eggermont AM,Kuiper-Kramer PA, van Eijk HG and Swaak AJ: Regulation of iron metabolism in the acute-phase response: Interferon gamma and tumour necrosis factor alpha induce hypoferraemia, ferritin production and a decrease in circulating transferrin receptors in cancer patients. Eur J Clin Invest 28: 520-527, 1998.
152. Bartalena L, Farsetti A, Flink IL and Robbins J: Effects of interleukin- 6 on the expression of thyroid hormone-binding protein genes in cultured human hepatoblastoma-derived (Hep G2) cells. Mol Endocrinol 6: 935-942, 1992.

153. Louagie H, Delanghe J, Desombere I, De Buyzere M, Hauser P and Leroux-Roels G: Haptoglobin polymorphism and the immune response after hepatitis B vaccination. Vaccine 11: 1188-1190, 1993.

154. Borthwick NJ, Lane T, Moyo N, Crook A, Shim JM, Baines I, Wee EG, Hawkins PN, Gillmore JD, Hanke T and Pepys MB: Randomized phase I trial HIV-CORE 003: Depletion of serum amyloid $\mathrm{P}$ component and immunogenicity of DNA vaccination against HIV-1. PLoS One 13: e0197299, 2018.

155. Creech CB, Frenck RW Jr, Sheldon EA, Seiden DJ, Kankam MK, Zito ET, Girgenti D, Severs JM, Immermann FW, McNeil LK, et al: Safety, tolerability, and immunogenicity of a single dose 4-antigen or 3-antigen Staphylococcus aureus vaccine in healthy older adults: Results of a randomised trial. Vaccine 35: 385-394, 2017

156. Blom M, Prag JB and Norredam K: Alpha 1-Acid glycoprotein, alpha 1-antitrypsin, and ceruloplasmin in human intestinal helminthiases. Am J Trop Med Hyg 28: 76-83, 1979.

157. Naylor C, Lu M, Haque R, Mondal D, Buonomo E, Nayak U, Mychaleckyj JC, Kirkpatrick B, Colgate R, Carmolli M, et al: Environmental enteropathy, oral vaccine failure and growth faltering in infants in bangladesh. EBioMedicine 2: 1759-1766, 2015.

158. Hwang SA, Kruzel ML and Actor JK: Lactoferrin augments BCG vaccine efficacy to generate $T$ helper response and subsequent protection against challenge with virulent Mycobacterium tuberculosis. Int Immunopharmacol 5: 591-599, 2005.

159. Carty CL, Heagerty P, Nakayama K, McClung EC, Lewis J, Lum D, Boespflug E, McCloud-Gehring C, Soleimani BR, Ranchalis $\mathrm{J}$, et al: Inflammatory response after influenza vaccination in men with and without carotid artery disease. Arterioscler Thromb Vasc Biol 26: 2738-2744, 2006.

160. Patel C and Shah HH: Membranous nephropathy and severe acute kidney injury following influenza vaccination. Saudi J Kidney Dis Transpl 26: 1289-1293, 2015.

161. Bos MP, Poolman J, Stork M, Tommassen JPM and Weynants V: Vaccine comprising protein NMB0964 from Neisseria meningitidis. US Patent 9,259,461. Filed March 6, 2009; issued August 4, 2011.

This work is licensed under a Creative Commons Attribution-NonCommercial-NoDerivatives 4.0 International (CC BY-NC-ND 4.0) License. 